\title{
EFEKTIFITAS MEDIA PEMBELAJARAN MATEMATIKA MENGGUNAKAN SOFTWARE ANIMASI BERBASIS MULTIMEDIA INTERAKTIF MODEL TUTORIAL PADA MATERI GARIS DAN SUDUT UNTUK SISWA SMP/MTS KELAS VII
}

\author{
Annisa Al Karimah ${ }^{1}$, Rusdi ${ }^{2}$, M. Fachruddin ${ }^{3}$ \\ ${ }^{1,2,3}$ Program Studi Pendidikan Matematika JPMIPA FKIP Universitas Bengkulu \\ Email :1 annisaalkarimah95@gmail.com, ${ }^{2}$ rusdipendmat12@gmail.com, ${ }^{3}$ mfachruddin.s@gmail.com
}

\begin{abstract}
Abstrak
Penelitian ini bertujuan untuk mengetahui tingkat efektifitas dari Media Pembelajaran Matematika Berbasis Multimedia Interaktif Materi Garis Dan Sudut yang telah dikembangkan. Jenis penelitian ini adalah penelitian pengembangan (Research and Development) dengan mengadopsi prosedur Analysis, Design, Development. Implementation, dan Evaluation (ADDIE). Penelitian dilakukan dalam tiga tahap yaitu: terdiri tahap analisis (analysis), tahap perancangan (design), dan tahap pengembangan (development) . Pada tahap pengembangan dilakukan uji efektifitas. Uji efektifitas Media pembelajaran dilakukan pada kelas VII F SMP IT IQRA’ Kota Bengkulu semester genap tahun ajaran 2016/2017 berjumlah 31 siswa. Instrumen penelitian ini adalah lembar efektifitas media. Hasil penelitian menunjukkan bahwa tingkat efektifitas media pembelajaran berbasis multimedia interaktif model tutorial pada pokok bahasan garis dan sudut di kelas VII SMP/MTs termasuk dalam kategori sangat efektif dari aspek aktivitas siswa dan guru, respon siswa, dan tes hasil belajar siswa dengan skor 4,23 .
\end{abstract}

Kata Kunci : Efektifitas, Media Pembelajaran, tutorial model, Multimedia Interaktif, Garis dan Sudut.

\begin{abstract}
This researh was aimed to know level of effectiveness from Mathematic Media Based On Tutorial Model Interactive Multimedia On The Developed Line And Angle Material. The design of this research was the development of research (Research \& Development) which is adapted from ADDIE procedure. This research done by three stage that is analysis, design, and development. The development of initial product was conducted by effectiveness test. The effectiveness of learning media was tried out to thirty one students grade VII students SMP IT IQRA' Bengkulu in second semester of Academic Year of 2016/2017. The instument of this research was media effectiveness sheet. The result of this research shown that the level of effectiveness Media Base On Tutorial Model Interactive Multimedia On The Developed Line And Angle Material Grade VII SMP included in very effective category with average score was 4,23. It was seen from activity students and teacher, students' responses and the achievement test.
\end{abstract}

Keyword : Effectiveness, Learning Media, Tutorial Model, Interactive Multimedia, Line and Angle Material.

\section{PENDAHULUAN}

Matematika termasuk salah satu cabang ilmu pengetahuan yang berperan penting dalam berbagai aspek kehidupan. Pelajaran matematika adalah proses yang disengaja dirancang dengan tujuan menciptakan suasana yang memungkinkan siswa melaksanakan kegiatan belajar matematika. Selama pelaksanaan pembelajaran matematika tersebut, guru berperan sebagai perancang selama proses kegiatan pembelajaran, sedangkan siswa merupakan pelaksana kegiatan pembelajaran. (Utama dkk,2012:51)

Selama proses pembelajaran matematika sebagian besar guru lebih aktif menjelaskan materi dan siswa dituntut mendengar, mencatat penjelasan guru, serta menyelesaikan latihan 
soal-soal yang ditentukan oleh guru. Hal ini yang membuat pembelajaran matematika yang masih bersifat teacher centered yaitu pembelajaran yang masih berpusat pada guru.

Salah satu cara yang membuat proses pembelajaran matematika lebih menyenangkan, dan lebih bersifat interaktif adalah dengan menggunakan media pembelajaran. Pemilihan media pembelajaran yang pas untuk siswa akan memudahkan dan menumbuhkan minat belajar siswa pada materi tertentu.

Media pembelajaran berbasis multimedia interaktif dengan menggunakan software animasi merupakan salah satu media pembelajaran dengan proses pembelajaran yang berpusat pada siswa. Pemanfaatan media pembelajaran software animasi berbasis multimedia interaktif dalam proses pembelajaran akan menggeser pembelajaran yang membosankan menjadi pembelajaran yang menyenangkan. Memanfaatkan multimedia interaktif menjadikan guru bukan lagi sebagai satu-satunya sumber belajar siswa dan multimedia interaktif diharapkan bisa membuat siswa aktif dalam belajar, sedangkan animasi pada media pembelajaran akan membuat media pembelajaran menjadi semakin menarik. Ketertarikan siswa akan media pembelajaran, juga akan meningkatkan motivasi belajar siswa.

Perkembangan teknologi informasi yang kian pesat memungkinkan seseorang melakukan eksplorasi data dan informasi secara lebih luas dan praktis. Pemanfaatan komputer dalam berbagai bidang pekerjaan dapat meningkatkan kinerja dan memungkinkan kegiatan dapat dilakukan dengan cepat, tepat dan akurat. Pemanfaatan komputer juga merupakan instrumen bagi guru untuk pengembangan media pembelajaran software animasi berbasis multimedia interaktif. Dengan berkembangnya media pembelajaran menggunakan sofware animasi berbantuan teknologi komputer dapat memudahkan peserta didik untuk mendapat sumber belajar yang lebih luas dan praktis sehingga tidak hanya memanfaatkan atau menggunakan buku cetak saja.

Hasil observasi yang dilakukan pada 18 Januari 2017 di SMP IT IQRA Kota Bengkulu ditemukan hambatan dalam proses belajar mengajar, yaitu kurangnya pemanfaatan media pembelajaran dengan unsur perangkat lunak yang mendukung. Masih sedikitnya guru yang menggunakan komputer sebagai sarana belajar atau media pembelajaran. Guru masih menggunakan buku sebagai sumber belajar dan papan tulis sebagai media pembelajaran, khususnya dalam mata pelajaran garis dan sudut. Hal ini membuat siswa merasa kurang tertarik dalam pembelajaran matematika yang akhirnya membuat siswa mengalami kesulitan dalam pelajaran matematika dan kurang memahami konsep matematika yang diberikan oleh guru.

Penelitian ini dilakukan dalam rangka mengefektifkan sebuah media pembelajaran dengan menggunakan sofware animasi. Efektifitas media pembelajaran dilakukan pada materi garis dan sudut agar bisa disampaikan menggunakan animasi menarik, sehingga pembelajaran tidak membosankan.

Berdasarkan latar belakang yang telah dikemukakan di atas, maka rumusan masalah yang akan dikaji dalam penelitian ini adalah Bagaimana tingkat efektifitas dari media pembelajaran berbasis multimedia interaktif model tutorial materi garis dan sudut yang telah dikembangkan?

Adapun tujuan penelitian ini adalah untuk mengetahui tingkat efektifitas dari media pembelajaran berbasis multimedia interaktif model tutorial materi garis dan sudut yang telah dikembangkan.

\section{A. Media Pembelajaran}

Secara harfiah "media berarti medium atau perantara. Dalam kaitannya dalam proses komunikasi pembelajaran ,media merupakan wahana penyalur pesan pembelajaran" (Hernawan dkk, 2008:11.18). Media pembelajaran menurut Heinich (1993) dalam Susilana dan Riyana (2009:6) merupakan "alat penyalur komunikasi, media berasal dari bahasa latin dan merupakan bentuk jamak dari kata "medium" yang secara harfiah berarti "perantara" yaitu perantara sumber pesan (a source) dengan penerima pesan (a receiver). Henich mencontohkan media ini seperti film, 
televisi, diagram, bahan tercetak(printed materials), komputer, dan instruktur".

\section{B. Multimedia Interaktif}

Multimedia didefinisikan oleh Haffost dalam Rusman (2013:149) sebagai "suatu sistem komputer yang terdiri dari hardware dan software yang memberikan kemudahan untuk menggabungkan gambar ,video ,fotografi, grafik dan animasi dengan suara ,teks, dan data yang dikendalikan dengan program komputer".

Daryanto (2013:51) menjelaskan bahwa "multimedia terbagi menjadi dua kategori, yaitu multimedia linier dan multimedia interaktif. Multimedia linier adalah suatu multimedia yang tidak dilengkapi dengan alat pengontrol apapun yang dapat dioperasikan oleh pengguna. Multimedia ini berjalan sekuensial (berurutan), contohnya: TV dan Film. Multimedia interaktif adalah suatu multimedia yang dilengkapi dengan alat pengontrol yang dapat dioperasikan oleh pengguna, sehingga pengguna dapat memilih apa yang dikehendaki untuk proses selanjutnya. Contoh multimedia interaktif adalah pembelajaran interaktif, aplikasi game, dan lain-lain".

Multimedia pembelajaran interaktif merupakan pembelajaran dengan menggunakan berbagai media yang dilengkapi dengan alat pengontrol yang dapat dioperasikan oleh pengguna dan pengguna dapat memilih apa pembelajaran yang dikehendakinya.

Karakteristik multimedia pembelajaran sebagaimana yang telah diungkapkan Daryanto (2013:53) bersesuaian dengan karakteristik multimedia pembelajaran yang disebutkan oleh Ariani dan Haryanto (2010:27), karakteristik multimedia tersebut dapat dilihat sebagai berikut:

1. Memiliki lebih dari satu media yang konvergen, misalnya menggabungkan unsur audio dan visual.

2. Bersifat interaktif, dalam pengertian memiliki kemampuan untuk mengakomodasi respon pengguna.

3. Bersifat mandiri, dalam pengertian memberi kemudahan dan kelengkapan isi sedemikian rupa sehingga pengguna dapat menggunakan tanpa bimbingan orang lain.

\section{Model Tutorial}

Tutorial didefenisikan sebagai bentuk pembelajaran khusus dengan pembimbing yang terkualifikasi, penggunaan miko komputer untuk tutorial pembelajaran. Tutorial dengan metode alternatif diantaranya bacaan, demonstrasi, penemuan bacaan atau pengalaman yang membutuhkan respon secara verbal dan tulisan serta adanya tujuan.

Tutorial adalah bimbingan pembelajaran dalam bentuk pemberian arahan, bantuan, petunjuk, dan moivasi agar para siswa belajar secara efisien dan efektif. Pemberian bantuan berarti membantu siswa dalam mempelajari materi pembelajaran. Petunjuk berarti memberikan informasi tentang cara belajar secara efisien dan efektif. Arahan berarti mengarahkan para siswa untuk mencapai tujuan masing-masing. Motivasi berarti menggerakkan kegiatan para siswa dalam mempelajari materi, mengerjakan tugas-tugas, dan mengikuti penilaian. Bimbingan berarti membantu para siswa memecahkan masalah-masalah belajar.

\section{Software Animasi}

Menurut Hasyim ( 2008:97), Software (Perangkat Lunak) adalah rangkaian instruksi elektronik yang memerintahkan komputer untuk melakukan tugas tertentu sesuai dengan perintah yang diberikan oleh seorang pengguna komputer.

Animasi adalah urutan frame yang ketika diputar dalam frame dengan kecepatan yang cukup dapat menyajikan gambar bergerak lancar seperti sebuah film atau video . animasi juga dapat diartikan dengan menghidupkan gambar, sehingga anda perlu mengetahui dengan pasti setiap detail karakter anda, mulai dari tampak (depan, belakang, 3/4 dan samping) detail muka si karakter dalam berbagai ekspresi (normal, diam, marah, senyum, ketawa, kesal dan lainnya) lalu pose/ gaya khas karakter bila sedang melakukan kegiatan tertentu yang menjadi ciri khas si karakter tersebut. (Purnama,2013:81).

Sofware animasi adalah Perangkat Lunak yang memuat efek-efek untuk menyajikan gambar bergerak lancar, sehingga gambar tersebut menjadi lebih hidup, menarik dan interaktif. 
Pembuatan media pembelajaran pada penelitian ini menggunakan software macromedia flash 8 dengan animasi 2D.

Animasi 2D adalah penciptaan gambar bergerak dalam lingkungan dua dimensi. Hal ini dilakuka dengan urutan gambar berturutturut atau "frame" yang mensimulasikan gerak oleh setiap gambar meunjukkan berikutnya dalam perkembangan bertahap langkahlangkah.

\section{METODE}

Jenis penelitian yang akan digunakan dalam penelitian ini adalah penelitian dan pengembangan (Research and development). Menurut Soenarto (dalam Tegeh, Jampel dan Pudjawan, 2014: xii) penelitian pengembangan adalah upaya untuk mengembangkan dan menghasilkan suatu produk berupa materi, media, alat dan atau strategi pembelajaran, digunakan untuk mengatasi pembelajaran di kelas/ laboraturium, dan bukan untuk menguji teori. Penelitian pengembangan ini menggunakan model ADDIE, model ADDIE merupakan salah satu model desain pembelajaran sistematik. ADDIE merupakan singkatan Analysis, Design, Development or Production, Implementation or Delivery and Evaluation. Pada penelitian ini hanya dilakukan tiga tahap penelitian yakni tahap analisis, desain dan pengembangan. Sasaran dalam penelitian efektifitas media pembelajaran software animasi berbasis multimedia integratif adalah siswa kelas VII SMP IT IQRA Kota Bengkulu pada tahun ajaran 2016/2017. Subjek uji coba lapangan terdiri dari 31 siswa pada kelas VII F SMP IT IQRA' Kota Bengkulu. kelas VII F dipilih karena siswa pada kelas itu lebih aktif dan kemampuan siswanya heterogen. Instrumen yang digunakan dalam penelitian ini adalah lembar lembar angket respon siswa, lembar pengamatan aktivitas guru dan siswa, dan tes hasil belajar. Teknik pengumpulan data yang dilakukan dalam penelitian ini adalah pengumpulan keefektifan media pembelajaran. Teknik analisis data yang digunakan adalah analisis efektiftas.

\section{HASIL DAN PEMBAHASAN}

Hasil peneitian pengembangan ini diperoleh dari uji efektifitas media pembelajaran.

\section{Uji efektifitas}

Uji efektifitas dilakukan untuk melihat keefektifan media pembelajaran. Media pembelajaran ini di uji cobakan pada 31 siswa kelas VII $F$ yang sedang mengikuti pembelajaran garis dan sudut. Uji efektifitas dilakukan di SMP IT IQRA Kota Bengkulu. Hasil uji efektifitas memberikan data berupa aktivitas dalam kegiatan belajar mengajar yang terdiri dari aktivitas siswa dan aktivitas guru dalam proses pembelajaran, respon siswa terhadap media dan tes hasil belajar siswa. Berikut hasil uji efektifitas dapat dilihat pada Tabel 3.

Tabel 3 Hasil uji efektifitas

\begin{tabular}{|c|c|c|}
\hline Analisis & $\begin{array}{c}\text { Skor } \\
\text { rata- } \\
\text { rata }\end{array}$ & Kriteria \\
\hline Aktivitas siswa & 4,14 & Efektif \\
\hline Aktivitas guru & 4,38 & $\begin{array}{c}\text { Sangat } \\
\text { efektif }\end{array}$ \\
\hline Respon siswa & 4,10 & Efektif \\
\hline $\begin{array}{c}\text { Tes Hasil } \\
\text { Belajar }\end{array}$ & 4,32 & $\begin{array}{c}\text { Sangat } \\
\text { efektif }\end{array}$ \\
\hline $\begin{array}{c}\text { Skor rata-rata } \\
\text { uji efektifitas }\end{array}$ & 4,23 & $\begin{array}{c}\text { Sangat } \\
\text { efektif }\end{array}$ \\
\hline
\end{tabular}

Berdasarkan analisis data yang diperoleh terlihat bahwa tingkat efektifitas produk media pembelajaran termasuk dalam kategori sangat efektif. Hal ini menunjukkan bahwa media layak digunakan dan memberikan manfaat pada proses pembelajaran. Hal ini juga diperkuat oleh respon siswa yang menyatakan media pembelajaran efektif digunakan serta hasil belajar siswa berada diatas nilai Kriteria Ketuntasan Minimal (KKM), yakni $\geq 73$, siswa juga memenuhi kriteria ketuntasan secara menyeluruh. Inii dilihat dari besarya presentase jumlah siswa yang tuntas sebesar $80,6 \%$ sehingga dapat dikatakan bahwa secara 
keseluruhan siswa telah mencapai kompetensi yang telah ditentukan. Berdasarkan analisis tersebut, maka media dapat dapat digunakan dengan melakukan beberapa perbaikan atau revisi menyesuaikan saran dan masukan dari siswa maupun guru hingga mengasilkan media pembelajaran matematika final.

\section{PENUTUP}

\section{Simpulan}

Berdasarkan hasil penelitian media pembelajaran matematika berbasis multimedia interaktif model tutorial pada pokok bahasan garis dan sudut di kelas VII SMP/MTs diperoleh kesimpulan tingkat efektifitas media pembelajaran berbasis multimedia interaktif model tutorial pada pokok bahasan garis dan sudut di kelas VII SMP/MTs termasuk dalam kategori sangat efektif dengan skor 4,23.

\section{Saran}

Saran-saran yang dapat diberikan penulis adalah sebagai berikut :

1. Media pembelajaran ini perlu dibuat fasilitas menggambar untuk melatih siswa membuat gambar sudut berbasis komputer dengan langkah manual agar siswa lebih interaktif dalam belajar mandiri.

2. Media pembelajaran multimedia interaktif hendaknya dilengkapi dengan fasilitas audio unTuk menunjang belajar siswa, selain penjelasan dari guru.

\section{DAFTAR PUSTAKA}

Ariani, Niken \& Haryanto, Dani. (2010). Pembelajaran Multimedia Di Sekolah Pedoman Pembelajaran Inspiratif, Konstruktif dan Prospektif. Jakarta: Prestasi Pustaka.

Daryanto . (2016). Media Pembelajaran. Yogyakarta: Gava Media.

Hasyim.(2008). Buku Pintar Komputer. Kriya Pustaka

Hernawan, Asep Herry \& dkk.(2008). Pengembangan Kurkulum dan
Pembelajaran. Jakarta : Universitas Terbuka.

Purnama, Bambang Eka.(2013). Konsep Dasar Multimedia. Yogyakarta : Graha Ilmu.

Rusman.(2013). Belajar dan Pembelajaran Berbasis Komputer. Bandung : Alfabeta Bandung.

Susi \& Riyana.(2009). Media Pembelajaran. Bandung : CV Wacana Prima .

Tegeh, Jampel \& Pudjawan.(2014). Model Penelitian Pengembangan. Graha Ilmu 